\title{
SHOPPING BEHAVIOUR CHINESE TOURISTS IN BALI
}

\author{
I Gusti Ayu Dewi Hendriyani \\ Lecturer, Department of Hospitality. \\ Sekolah Tinggi Pariwisata Nusa Dua Bali. \\ Indonesia
}

\begin{abstract}
In tourism sector, shopping is a favorite activity for tourists especially for Chinese tourists. Shopping behaviour can be different according to their interest. This research aims at investigating the shopping behaviour of the tourists from China as the second major market in Bali. The questionnaire by chinese respondents is separated into three parts, that are Personal information, Shooping pattern and In store shopping experience. The method using frequency of likert scale by Chinese guests visiting Bali in 2015 with total 104 persons.

The result of this research are that in Shopping Pattern : chinese tourist likes to shop at traditional Bali souvenir shop, buy alot of walet product, get information from their guide, shopping for 3 days, with local currency (rupiah) and shopping based of friends and relatives recommended. And in Store shopping experience, Chinese tourist in product attributes (A) prefer quality of material, in store shopping environment (B) prefer the need fitting room facilities, for salesperson service (C) they need good product knowledge and for store policy (D) likes after sales service. Results of this research can be taken into consideration for all stakeholders or parties who handle Chinese tourists, especially for entrepreneurs who provide services souvenirs or a travel agency that handles Chinese tourists in Bali
\end{abstract}

Key words: Tourism, Souvenir, Chinese Tourist, Shopping behaviour

\section{INTRODUCTION}

Bali is a tourist destination in Indonesia most favored by both foreign tourists and domestic tourists. As a major tourist destination in Indonesia, Bali has become a barometer of the tourism development in the country. Besides being very popular among foreign tourists, Bali is also a major destination for domestic tourists to vacation, conduct business and other activities. According to statistics of tourist arrivals in 2015 of Bali Provincial Tourism Office (January 2016), the total foreign tourists visiting Bali in year 2015 are 3,766,638 peoples with the distribution of 20 countries. There are Australia (24.16\%), China (17.20\%), Japan (5.70\%), Malaysia (4.76\%), UK $(4.19 \%)$, South Korea (3.82\%), USA (3.34\%), France $(3.28 \%)$, Taiwan $(3.11 \%)$, Germany $(3.01 \%)$, India (2.97\%), Netherlands (2.04), New Zealand (1.76\%), Russia (1.29\%), Canada ( $1.12 \%)$, Hong Kong (0.92\%), Philippines $(0.87 \%)$, Switzerland $(0.86 \%)$ and Italy (0.83\%). And according to the Central Statistics Agency (BPS) of Bali (February, 2016) The arrival of foreign tourists (tourists) to Bali in February 2016 reached 375.744 people, with tourists who come through the airport as many as 367.024 people, and that is through sea ports amounted to 8.720 people. The number of foreign tourists to Bali in February 2016 increased by 10.84 percent compared to February 2015 and increased by 7.17 percent compared to the month of January 2016. By nationality, most foreign tourists came to Bali in February 2016 is the nationality of foreign tourists to China, Australia, Japan, Malaysia, and the United Kingdom with percentages respectively by 30.45 percent, 18.17 percent, 6.13 percent, 3.86 percent and 3.70 percent
Potential Chinese tourists ranked second in foreign tourists who visit directly to Bali in 2015, and getting increase in year 2016, it was felt necessary attention by tourism stakeholders in Bali. The Chinese government it self since 1995 began to allow its citizens to travel to tourist destinations in the region have the status of ADS (Approved Destination Status). To avoid the return of their citizens and other reasons, Chinese government only allows citizens to travel abroad in the form of an entourage. They must be organized by a travel agent who has been licensed from CNTA (China National Tourism Administration) and led by a tour guide. Since then more and more Chinese citizens who travel to foreign countries that in 2003 the number had reached 20.2 million Chinese Outbound Travelers in the same year. In 2004 the number of Chinese Outbound Travelers reaches 23 million people of which $20 \%$ of them visited the ASEAN countries (WTO Mertha: 2006).

The island of Bali is still a powerful magnet for the Indonesian tourism industry in attracting foreign tourists. Its proving that Bali received 2 (two) awards as the best destination and the best Overseas Tourisma City in year 2014. This award is given by C-Trip an influential online marketing tourism in China (PRC). C-Trip annual event held Top 10 Best Tourism Destination Network Selection and Award Ceremony. The awards ceremony took place in the city of Lijiang, Yunnan Province on January 10, 2015. C-Trip Award considerable influence on the market in China, given the company controls 55.9\% market share of online by Ministry of Tourism Republic Indonesia (RI) give serious attention to the breakthrough campaign using digital line (on-line). Various activities such as mobile apps, digital campaigns, interactive 
campaigns, viral marketing (face book, twitter, you tube, blogging, etc) will be intensified. Digital promotion has a strong influence and has a broad reach and faster can be realized with relatively cheap budget. $70 \%$ of Chinese travelers, to get information about Indonesia, they got from the internet. It is a challenge for us to intensify tourism promotion strategy through digital media. In addition to the promotion and marketing, serious attention is given to accessibility, especially direct flights to China's major cities such as Shanghai, Guangzhou, Shenzhen, Ningbo, Hangzhou, Nanjing, and other major cities as the 10 secondary cities. Ministry of Tourism RI and the China National Tourism Administration (CNTA) is determined to increase mutual tourist visits of up to 2 million tourists by the end of 2015. This determination is a collective spirit that was embodied in the MoU tourism cooperation between the two countries. In January to November 2014 the number of foreign tourists visiting China to Indonesia as many as 883.725 foreign tourists or ranks the top 4 after the tourists from Singapore as many as 1,32 million, 1,12 million Malaysia, and Australia 996.032 tourists. PRC foreign tourists visiting Indonesia to an average of 4 to 5 days with expenditures of approximately US \$ 100 to US \$ 110 per day, while on vacation generally they chose the long holiday season such as; Chinese New Year, school holidays in June-July, the Labor Day holiday, and the Golden Week holiday which took place in October. (Puskompublik- Kemenpar RI, January 12, 2015)

Bali tourism industry seriously continue to work on the Chinese tourist market with deep buying power for more vacation and visit the island. Chinese tourists spending money` market with 'low. Though they have the potential to 'high tourism' because a lot of people rich. Now that he wants to seriously working on the tourist market of the upper class or jet-setting of the Bamboo Curtain country. It was one part so that Bali could increase the number of visits and the quality of its tourist. Number of tourists visiting China over the past few years continue to rise 15-24 percent annually. That's because the citizens of the country like nature and culture on the island. (Indonesia.go.id)

According to Han Shen (2012) in The Regional Major Source Markets of China Outbound Tourism stated that in 2011, there were 70,25 million mainland tourists traveling abroad /outbound tourism. It added that the islands of Southeast Asia is the first choice for tourists from Beijing (China) today. Three top island destinations are Phuket, Maldives and Bali (by Mimi Li (2012) in the Awakening Dragon). China Outbound Tourism Market to mention that the Chinese market is the third largest market in the consumption of luxury goods. The priority of spending time and money they are carrying out overseas travel / outbound tourism (75.1\%) and traveled in the country $(69.3 \%)$. The source of their information via the Internet $(82.40 \%)$, and via travel agent $(77.30 \%)$. And their biggest concern at the destination is a guarantee of security, problems of communication / language and look for a different experience.

According to Tiger Wu Bihu (2012) in the Understanding China: A C.H.I.N.A. Model of Chinese and Consumer Behavior, confirmed that Chinese tourists would prefer to stay at the 2 star hotels, eat Chinese food is cheap and busy shopping all day. Chinese tourists mostly traveled with friends $(29.0 \%)$ and family members (27.8\%). Motivation Chinese tourists traveled with for individual and group were highest for shopping $(71.2 \%)$, followed by entertainment (12.9\%), sightseeing (11.6\%) and finally the Food and Beverage (1.2\%). Share experiences with friends and family to buy a gift for them is a reason why Chinese tourists to shop a lot during the tour.

Expenditure incurred on overseas Chinese travelers ranks first in Asia and the Pacific region with an average of US \$ 874 per person. Similarly, according to the results announced by $\mathrm{CNN}$ website and a travel agency. The survey involved nearly 4,000 respondents and several major markets, including Mainland China, Hong Kong, Taiwan, Japan, and Australia. Among the top five shopping centers in the world, Hong Kong is the ideal destination for tourists from Mainland China. Known from China's State Tourism Agency, ten years, the number of Chinese tourists abroad increased. The number of Chinese tourists increased to 70 million in 2011 from 1.6 million in 2002, a threefold increase over. These last years, overseas Chinese tourists to increase with increasing strength of China, the rising standard of living as well as the expansion of openness. During these ten years, China has become the largest source of tourists in Asia and countries overseas consumption in the world's third largest (Daily analysis, November 5, 2012)

Bali as one of the favorite destinations for tourists in the country and the world for tourists archipelago abroad, in providing services to tourists- provide gifts or souvenirs can be purchased for private collections and souvenirs for family and friends. Souvenirs in Indonesia dictionary (2010) means something brought from traveling or may be called as a souvenir. Many places in Bali to be able to shop for souvenirs from Bali. In a review "5 Points Shopping bymost favorite in Bali" for the domestic market or foreign tourist usually enjoys shopping in: the art market sukawati, Joger Shop "factory of words", Erlangga Bali, Krisna Bali and art market Kumbasari. (www.jawarakampung. blogspot.com).

Interviews with several guides of European market and Mandarin in the initial survey of this study said that foreign tourists also have plenty of places to shop for souvenirs typical of Bali in accordance with the tastes of tourists such as Duty Free Shop (DFS) in Kuta, Centro Shopping Mall in Kuta, Bali Collection in the area of Nusa Dua, Ubud Art Market and other places. Competition in business souvenirs in Bali can we meet along the tourist areas as well as on tourism in Bali both traditional and modern. Sukawati market is an example for the traditional and took center souvenirs typical of Bali is an example for 
the modern. For Chinese market, according to the tour guides mandarin incorporated in Indonesian Tourist Guide Association (HPI) Division of Mandarin commonly called Bali Liang, they often buy souvenirs of swallow birdnest product (packaging), Balinese coffee, clothes, dry food and stones jade in some centers for souvenirs typical of Bali in cooperation with Travel Bureau (BPW) mandarin market with totaling $35 \mathrm{BPW}$. Competition of the commission of the central shop for souvenirs to BPW or the guide, one of the reasons travelers often choose to shop at a gift shop than in the traditional market. Given the size of the Chinese market in the future, which already ranks second visit in Bali after Australia, it would need to be assessed on the shopping behavior of Chinese tourist souvenirs in Bali. It would be very useful for entrepreneurs itself, to BPW handle Chinese tourists, the guides and of course the government in providing quality service to Chinese tourists both services and products that will be offered.

Based on the description on the background of the above problems, the formulation of the problem is: "How does the shopping behavior of Chinese tourist to buy souvenirs in Bali?". In accordance with the formulation of the problem above, the purpose of this study was to determine the behavior of shopping souvenirs Chinese tourists in Bali. The results of this study are expected to: a. can be helpful for the scientific development of tourism in Bali. To further research is expected to be a reference in advanced research in the future, $b$. as input for the management of the Chinese market BPW to provide an overview of the shopping behavior of Chinese tourist to buy souvenirs in Bali and the importance of always improving service quality and satisfaction for Chinese tourists in Bali, c. as an input to the provincial government of Bali in developing a center for souvenirs in Bali, both the facilities and the quality of service by human resources

\section{METHOD}

The location of this research is on the hotels where Chinese tourists will check out ahead of their departure to the airport, return to their respective countries. Hotels usually they occupy spread in the area of Kuta, Jimbaran, Nusa Dua and Pecatu. The hotel will be sought based on information from market BPW BPW Mandarin numbering 35 in the study period is from December 2015Pebruary 2016

The study population according to Malhotra (2005: 364) states that the population is a combination of all the elements that have a series of similar characteristics, which include rules for the benefit of the marketing research problem. Pramesti (2006: 2) states that the population is the whole object of concern in a study. The population in this study are Chinese tourists visiting Bali study period is from December 2015-Pebruary 2016. While the sample of this research is to determine the amount of samples taken in this study by using the formula slovin as follows:

\begin{tabular}{lll} 
& $\mathrm{n}=$ & \multicolumn{1}{c}{$\mathrm{N}$} \\
& & $\mathrm{N}(\mathrm{e})^{2}+1$ \\
$\mathrm{n}$ & $=$ & Total sample (respondent of research). \\
$\mathrm{N}$ & $=$ Total population. \\
$\mathrm{e}$ & $=$ Sample tolarance $(10 \%)$. & \\
1 & $=$ Konstanta.
\end{tabular}

Data collection techniques used in this study are: a. questionnaire that data collection techniques by spreading the questionnaire to be filled by Chinese tourists after they check out of the hotel to the airport / airport Ngurah Rai Bali, b. structured interview is a question and answer by using a list of questions prepared to ask of Tour Leader, Tour Guide, Manager Shop Souvenirs, Travel Bureau (BPW) market Mandarin (Chinese), the Association of ASITA division Mandarin, the Association of Indonesian Tourist Guide Association (HPI ) BaliDivision Mandarin (Bali Liang), c. literature, with the aim of obtaining an overview and clear guidelines on the spending behavior of tourists during tourist trip as previous studies, journals, articles and more.

The technique of collecting samples used in this study is a non-probability sampling (Kusmayadi, 2000: 140). Sampling was done by using purposive sampling cater to tourists with particular consideration to the amount that has been allocated. In this study, will be sought Chinese tourists will check out after a trip / trip them in Bali. Questionnaires will be in English, and Mandarin. According to BPS Bali in 2016 (1January 2016) the number of Chinese tourists from January s / d September 2015 was 241.439 people. So that the number of Chinese tourists monthly average 241.439 people are divided into 9 months was 26.826 people.

This study was a descriptive study. According to Whitney in Nazir (2005: 55) is a descriptive study with a fact-finding correct interpretation. The method used in this research is descriptive survey method. This method is held to obtain the facts of the presenting symptoms and seek factual information, both about the situation of social, economic and political of a group or a region. The main objective of this research is to solve problems, not to test the hypothesis (Sevilla: 1993). The steps in this analysis are: a. formulate problems, b. determining the variables studied, c. perform data analysis by finding the frequency of shopping options souvenirs Chinese tourists in Bali and its importance, d. draw a conclusion

\section{FINDINGS AND DISSCUSION}

\section{Literature Review}

Research by Dewi Hendriyani, Nyoman Arcana and Nengah Wirata (STP Nusa Dua Bali: 2011) with the title "factor that determines the satisfaction of tourists China Group Inclusive Tour (GIT) for products Chinese Restaurants in Badung-Bali" using confirmatory factor 
analysis with 4 factor is factor atmosphere (4 variables), the factors of food and beverages (4 variables), a service factor (3 variables) and the cleanliness factor (3 variables). The results of this study using SPSS 17:00 is: the most decisive factor is the factor of the food and beverage / food and beverage (F2) followed by a factor of service / service (F2) while variable that matters is variable $\mathrm{X} 5$ is the taste, followed by variable X1 is decor, Overall rating China GIT are satisfied with the products Chinese restaurants in the Badung regency of Bali with a value of 51.28 percent of the total respondents.

Journals by Xinran Y.Lehto et al (2004) with the title "Tourist shopping preferences and expenditure Behaviours: The case of the Taiwanese outbound market" in the Journal of Vacation Marketing, using survey data Taiwan outbound travelers in 2004. This study qualitatively assess options shopping and tourist shopping behavior associated with socio-demographic characteristics and attributes of their journey. The results of this study that a tourist destination, the force / travel choice, aged tourists and sex tourists is a significant factor affecting the amount of money spent and the type of goods they buy. The main question that has been posed to tourists personally like: what are the most popular items purchased by tourists in accordance with the demographic aspects of tourist destination and the factors which can be used to predict the level of expenditure of tourists in shopping.

Journals by Choi, T.-M., et al. (2007) with the title of Shopping behaviors of individual Chinese tourists from the Mainland to Hong Kong in Tourism Management Journal using survey data mainland tourists / Chinese Mainland (CM) which menggunjungi Hong Kong in the form of individual visits / Individual Visit Scheme (IVS). This study uses a qualitative method based on the in-store shopping experience construct (ISSEC) from Terblanche and Boshoff (2003) with five dimensions of ISSEC namely: namely, personal interaction, merchandise value, internal store environment, merchandise variety and assortment, and complaint handling in fashion products at four study sites. Results from this study that the decision to buy based on their own thoughts. Of the four dimensions of the in-store shopping experience, there are 2 important factors that attribute the product and service sales. Then the product attributes are two the most significant factor is the price and size. And of the four characteristics of mainland tourists to Hong Kong, tourists from Shanghai were most concerned with the comfort factor. All studies and journals above, can be a basic consideration in research on shopping behavior of Chinese tourist souvenirs in Bali

\section{Result}

The results of the recap characteristics of the respondents in this study using the opinion of the Chinese tourists who are on vacation and shop for souvenirs in Bali during the study period. Importance description of the characteristics of the respondent because many aspects that influence the satisfaction of tourists during shop for souvenirs in Bali. Analysis of the characteristics of respondents is comprised of: home city / state, age, sex, status, occupation, education, length of stay. From the research, it was found that the characteristics of Chinese tourists coming to Bali in the study period are as follows: a. country of origin: Taiwan, China, Hong Kong, b. Traveller age: between 30 and 50 years, c. gender: $50 \%$ male and $50 \%$ female, d. status: married and single $80 \%$ to $20 \%$, e. Occupation: leader of the company / factory $5 \%$, $35 \%$ self-employed, employee / employee (government / private) $60 \%$, f. Bachelor $50 \%$, 50\% high school, g. Average length of stay: 4 days

Results of the questionnaire the frequency of tourist shopping pattern is a pattern of tourist spending with total respondents 104 people obtained the following results:

Table 5.1

Spending Patterns Chinese tourists shop for souvenirs in Bali

\begin{tabular}{|l|l|l|l|l|l|}
\hline NO & \multicolumn{1}{|c|}{ Items } & \multicolumn{1}{|c|}{ A } & \multicolumn{1}{c|}{ B } & \multicolumn{1}{c|}{ C } & \multicolumn{1}{c|}{ D } \\
\hline 1 & Favorite Store Type & $5 \%$ & $20 \%$ & $30 \%$ & $\mathbf{5 0} \%$ \\
\hline 2 & Shopped in Bali & $\mathbf{5 0 \%}$ & $30 \%$ & $15 \%$ & $5 \%$ \\
\hline 3 & Kind of Product & $\mathbf{5 0 \%}$ & $5 \%$ & $40 \%$ & $5 \%$ \\
\hline 4 & Know about product & $5 \%$ & $20 \%$ & $\mathbf{5 0 \%}$ & $25 \%$ \\
\hline 5 & Spend on Shopping & $5 \%$ & $15 \%$ & $\mathbf{5 0 \%}$ & $30 \%$ \\
\hline 6 & Payment method & $15 \%$ & $\mathbf{4 0 \%}$ & $30 \%$ & $5 \%$ \\
\hline 7 & Making decision & $40 \%$ & $\mathbf{5 0} \%$ & $5 \%$ & $5 \%$ \\
\hline
\end{tabular}

Source: Data processed in 2016

Based on the above data, that the spending patterns of Chinese tourists in Bali is that they prefer shopping at the center by-Balinese, in stores that sell swallow because their choices more on the types of souvenirs Swallow, they get the information from the guide, shopping for 3 day, with the rupiah and shop based on the opinions of family or friends. The results of the questionnaire recapitulation of rating shopping experience (shopping experience) that includes shopping experience consisting of product attributes (A), shopping atmosphere (B), the seller service (C), and store policy (D) in get the following results:

Tabel 5.2

Recapitulation Respondents Frequency Response Product Attribute (A)

\begin{tabular}{|l|c|c|c|c|c|c|}
\hline $\begin{array}{c}\text { A. } \\
\text { Product } \\
\text { Attribute }\end{array}$ & Size & $\begin{array}{c}\text { Quality of } \\
\text { Material }\end{array}$ & $\begin{array}{c}\text { Pric } \\
\mathrm{e}\end{array}$ & $\begin{array}{c}\text { Packagin } \\
\mathrm{g}\end{array}$ & $\begin{array}{c}\text { Tota } \\
1\end{array}$ & $\%$ \\
\hline $\begin{array}{l}\text { Stronly Un } \\
\text { important }\end{array}$ & 0 & 0 & 0 & 0 & 0 & 0 \\
\hline $\begin{array}{l}\text { Not } \\
\text { Important }\end{array}$ & 0 & 0 & 0 & 0 & 0 & 0 \\
\hline $\begin{array}{l}\text { Quite } \\
\text { Important }\end{array}$ & 10 & 2 & 2 & 0 & 14 & $\begin{array}{c}13,46 \\
\%\end{array}$ \\
\hline $\begin{array}{l}\text { Important } \\
\text { Imply }\end{array}$ & 15 & 20 & 10 & 5 & 50 & $\begin{array}{c}48,07 \\
\%\end{array}$ \\
\hline $\begin{array}{l}\text { Important } \\
\text { Total }\end{array}$ & 35 & 34 & 22 & 13 & 104 & $\begin{array}{c}38,46 \\
\%\end{array}$ \\
\hline
\end{tabular}


A. Product attributes (Product Attribute) consisting of four indicators are: size (size), material quality (quality of material), price (price), packaging (packaging) with a total of 104 respondents get results in accordance with Table 5.2, where the result that Chinese tourists attach great importance to the quality of materials / material as an attribute of a product with the highest value of: $48.07 \%$. From the findings on product attributes in accordance with the reality on the ground is that Chinese tourists in Bali when they shop at their good taste with good product quality is of course also the product price is also high. This was confirmed in some people after their tour guide mandarin they confirmed that Chinese tourists will choose a quality product

Tabel 5.3

Recapitulation Respondents Frequency Response Shopping Environment (B)

\begin{tabular}{|l|c|c|c|c|c|c|}
\hline \multicolumn{7}{|c|}{ Shopping Environment (B) } \\
\begin{tabular}{|l} 
Bhopping \\
Environment
\end{tabular} & $\begin{array}{c}\text { Displa } \\
\mathrm{y}\end{array}$ & $\begin{array}{c}\text { Fitti } \\
\text { ng } \\
\text { Roo } \\
\mathrm{m}\end{array}$ & $\begin{array}{c}\text { Shoppi } \\
\text { ng } \\
\text { Bags }\end{array}$ & $\begin{array}{c}\text { Prod } \\
\text { uct } \\
\text { Poste } \\
\text { rs }\end{array}$ & Total & $\%$ \\
\hline $\begin{array}{l}\text { Strongly Un } \\
\text { important }\end{array}$ & 0 & 0 & 0 & 0 & 0 & 0 \\
\hline $\begin{array}{l}\text { Not } \\
\text { Important }\end{array}$ & 1 & 1 & 1 & 1 & 4 & $3,84 \%$ \\
\hline $\begin{array}{l}\text { Quite } \\
\text { Important }\end{array}$ & 10 & 10 & 10 & 10 & 40 & $38,46 \%$ \\
\hline Important & 10 & 20 & 10 & 10 & 50 & $48,07 \%$ \\
\hline $\begin{array}{l}\text { Strongly } \\
\text { Important }\end{array}$ & 4 & 2 & 3 & 1 & 10 & 9,61 \\
\hline Total & 25 & 33 & 24 & 22 & 104 & $100 \%$ \\
\hline
\end{tabular}

Source: Data processed in 2016

C. Shopping Environment consisting of four indicators namely: display, fitting room, shopping bags and Product posters with a total of 104 respondents get results in accordance with Table 5.3 where the result is that Chinese tourists attach great importance to their locker room facilities (fitting room) with the highest value of: $48.07 \%$. Results confirmed in the field with some of the Chinese-language guides that most travelers when buying clothing products requires the locker room (fitting room).
Tabel 5.4

Recapitulation Respondents Frequency Response Salesperson Service (C)

\begin{tabular}{|l|l|l|l|l|l|l|}
\hline $\begin{array}{l}\text { C. } \\
\text { Salesperson } \\
\text { Service }\end{array}$ & $\begin{array}{l}\text { Appera } \\
\text { nce }\end{array}$ & $\begin{array}{l}\text { Attitu } \\
\text { de }\end{array}$ & $\begin{array}{l}\text { Initi } \\
\text { ative }\end{array}$ & $\begin{array}{l}\text { Product } \\
\text { Knowled } \\
\text { ge }\end{array}$ & $\begin{array}{l}\text { Tot } \\
\text { al }\end{array}$ & $\%$ \\
\hline $\begin{array}{l}\text { Strongly Un } \\
\text { imprtant }\end{array}$ & 0 & 0 & 0 & 0 & 0 & 0 \\
\hline Not Important & 1 & 1 & 0 & 1 & 3 & $2,88 \%$ \\
\hline $\begin{array}{l}\text { Quite } \\
\text { Important }\end{array}$ & 5 & 5 & 5 & 5 & 20 & $\begin{array}{l}19,23 \\
\%\end{array}$ \\
\hline Important & 6 & 10 & 10 & 4 & 30 & $\begin{array}{l}28,84 \\
\%\end{array}$ \\
\hline $\begin{array}{l}\text { Strongly } \\
\text { Important }\end{array}$ & 8 & 10 & 13 & 20 & 51 & 49,03 \\
\hline Total & 20 & 26 & 28 & 30 & 10 & $100 \%$ \\
\hline
\end{tabular}

C. Service saleswoman (Salesperson service) consisting of four indicators namely: appearance (appearance), behavior (attitude), initiative (initiative), and knowledge of the product (product knowledge) with a total of 104 respondents get results in accordance with table 5.4, where the result that Chinese tourists concerned with their knowledge of the product (product knowledge) with the highest value of: $49.03 \%$. These findings were confirmed in the field after a few guides mandarin stated that Chinese tourists will be severely affected if the shop is no clear information about the product from the clerk on duty, especially more so if they can speak Mandarin.

Tabel 5.5

Recapitulation Respondents Frequency Response Store Policy (D)

\begin{tabular}{|c|c|c|c|c|c|c|}
\hline $\begin{array}{r}\text { D. } \\
\text { Store Policy }\end{array}$ & $\begin{array}{l}\text { Open } \\
\text { Hours }\end{array}$ & $\begin{array}{c}\text { Return } \\
\text { or } \\
\text { exchang } \\
\text { e }\end{array}$ & $\begin{array}{c}\text { After } \\
\text { sales } \\
\text { servic } \\
\text { e }\end{array}$ & $\begin{array}{l}\text { Payment } \\
\text { methods }\end{array}$ & $\begin{array}{c}\text { Handl } \\
\text { ing } \\
\text { Comp } \\
\text { laint }\end{array}$ & $\begin{array}{c}\text { Total } \\
+\%\end{array}$ \\
\hline $\begin{array}{l}\text { Strongly } \\
\text { Un } \\
\text { important }\end{array}$ & 0 & 0 & 0 & 0 & 0 & 0 \\
\hline $\begin{array}{l}\text { Not } \\
\text { Important }\end{array}$ & 0 & 0 & 0 & 0 & 0 & 0 \\
\hline $\begin{array}{l}\text { Quite } \\
\text { Important }\end{array}$ & 20 & 10 & 5 & 10 & 45 & $\begin{array}{c}43,26 \\
\%\end{array}$ \\
\hline Important & 5 & 5 & 5 & 10 & 25 & $\begin{array}{c}24,03 \\
\%\end{array}$ \\
\hline $\begin{array}{l}\text { Strongly } \\
\text { Important }\end{array}$ & 5 & 5 & 14 & 10 & 34 & 32,69 \\
\hline Total & 30 & 20 & 24 & 30 & 104 & $100 \%$ \\
\hline
\end{tabular}

Source: Data processed in 2016

D.Policy Store (Store policy) which consists of five indicators namely: open time (open store), exchange / refund (return / exchange), after-sales services (afther sales service), method of payment (payment method) and penanaganan complaints (handling complaint) with a total of 104 respondents get results in accordance with table 5.5, where the result that Chinese tourists emphasizes the importance of after-sales services (afther sales service) with the highest value of: $32.69 \%$. These findings were confirmed in several guides after Mandarin is that the rating 
after the last swallow the product, especially shopping certificates that can be obtained by tourists when they are at the airport. If there are obstacles the store can come to the airport to clarify about the products that have been purchased.

\section{Conclutions}

From the discussion in the previous chapter was concluded as follows: a. spending patterns souvenirs Chinese tourists in Bali, prefer shopping at the center byBalinese, in stores that sell swallow because their choices more on the types of souvenirs Swallow, they get the information from the guide, shopping for 3 days, with rupiah and shop in the opinion of family or friends, $b$. shopping experience by-by Chinese tourists in Bali, the product attribute (A) more important the quality of the material, the shopping atmosphere (B) the room try / replace, the seller service $(C)$ more important knowledge of the seller, and on the policy store (D ) more important service after the purchase.

Suggestions in this research are: a. for stakeholders who deal with tourists China (Chinese TA market, Shop Souvenirs, and guides mandarin) in dealing with Chinese tourists should be able to fix a factor that has not been good and sustain factors already good, b. for the government to pay more attention to product quality and infrastructure for tourists, especially the Chinese in order to maintain the satisfaction of tourists, c. for other researchers, so that the research can be continued, especially broader view of Chinese tourists' satisfaction of their arrival in Bali until they return to their country of departure.

\section{REFERENCES}

(1) BPS Propinsi Bali. Perkembangan Pariwisata Bali Juni 2012. 1 Agustus 2012

(2) Bihu Wu. 2012. Understanding China: A C.H.I.N.A. Model of Chinese and Consumer Behavior The $4^{\text {th }}$ Biennial ITSA Conference, Bali Tourism Institute.

(3) Choi,T.-M., et.al.2007. Shopping Behaviors of individual tourist from the Chinese Mainland to Hong Kong. Tourism Manajemen, doi: 10.1016/j.tourman.2007.07.009

(4) Dewi Hendriyani dkk.2011. Penelitian: "Faktor Yang Menjadi Penentu Kepuasawan Wisatawan China Group Inclusive Tour (GIT) terhadap Produk Restoran China di Kabupaten Badung-Bali”. Penelitian pada Pusat Penelitian dan Pengabdian pada Masyarakat. Sekolah Tinggi Pariwisata Nusa Dua Bali

(5) Gonroos,C.1990. Service manajemen Marketing. New York: McGraw Hill-USA

(6) Han Shen.2012. The Major Regional Source Markets of China Outbound Tourism. The $4^{\text {th }}$ Biennial ITSA Conference, Bali Tourism Institute.

(7) Hudson,S.2008. Tourism and Hospitality Marketing, A Golobal Perspective. India:SAGE Chennai

(8) Indonesia.go.id. Provinsi Bali 2012. "Bali Serius Garap Wisatawan China Berkantong Tebal" Portal Nasional Republik Indonesia. Selasa, 11 September 2012

(9) ICR.2011. Development Customer Insight: The Determination of Customer Preferences. www.icrsurvey.com. 8 Juni 2011

(10) Kotler,P;Bowen,J.T; Makens,JC.2010. Marketing for Hospitality and Tourism. Pearson Prentice Hall. New Jersey.USA

(11) Kusmayadi dan Sugiarto, Endar. 2000, Metode Penelitian.

(12) Mertha, I Wayan. 2006. Potensi Pasar Wisatawan China: Peluang dan Tantangannya. Makalah Seminar Sehari dalam rangka Dies Natalis Sekolah Tinggi Pariwisata Nusa Dua Bali

(13) Mimi Li.2012. Awakening Dragon. China Outbound Tourism Market. The $4^{\text {th }}$ Biennial ITSA Conference, Bali Tourism Institute.

(14) Xinran Y.Lehto.2004. Journal: "Tourist shopping preferences and expenditure behaviours: The case of the Taiwanese outbound market". Journal of Vacation Marketing - October 2004 vol. 10 no. 4 320-332 ., Purdue University-USA 